\title{
APRESIASI DAN KRITIK TERHADAP ALIRAN-ALIRAN FILSAFAT PENDIDIKAN
}

\author{
Oleh : Romdloni
}

\begin{abstract}
ABSTRAK
Filsafat adalah hasil pemikiran ahli-ahli filsafat atau filosof-filosof sepanjang zaman diseluruh dunia. Sejarah pemikiran filsafat yang amat panjang dibandingkan dengan sejarah ilmu pengetahuan, telah memperkaya khazanah (perbendaharaan) ilmu filsafat. Sebagai ilmu tersendiri filsafat tidak saja telah menarik minat dan perhatian para pemikir, tetapi bahkan filsafat telah amat banyak mempengaruhi perkembangan seluruh budaya umat manusia. Sebagai hasil dari pemikiran para filosuf, filsafat telah melahirkan berbagai macam pandangan dan aliran yang berbeda-beda. Pandangan-pandangan filosuf itu ada kalanya saling menguatkan dan ada juga yang saling berlawanan. Hal ini antara lain disebabkan oleh pendekatan yang mereka pakai juga berbeda-beda walaupun untuk objek dan masalah yang sama. Karena perbedaan dalam pendekatan itu, maka kesimpulan yang didapat juga akan berbeda. Perbedaan pandangan filsafat tersebut juga terjadi dalam pemikiran filsafat pendidikan, sehingga muncul aliran-aliran filsafat pendidikan. Beberapa aliran filsafat pendidikan tersebut yaitu perenialisme, esensialisme, progresivisme, rekonstruksionisme dan eksistensialisme.
\end{abstract}

Kata kunci : Apresiasi, Kritik, Filsafat Pendidikan

\section{A. Pendahuluan}

Filsafat Sebagai induk dari ilmu pengetahuan (the mother of sciences) pada dasarnya bermaksud untuk menjawab seluruh problematika yang ada maupun yang mungkin ada. masalah yang berkaitan dengan trilogi metafisika, yaitu manusia, Tuhan dan alam beserta problematikanya menjadi isu utama yang yang menjadi kajian filsafat.

Dalam proses pertumbuhannya, filsafat sebagai hasil pemikiran para ahli filsafat sepanjang kurun waktu dengan obyek permasalahan hidup di dunia telah melahirkan berbagai macam pandangan, adakalanya satu dengan lainnya bersifat saling menguatkan tetapi tidak jarang pula yang berbeda atau bahkan saling berlawanan. Hal ini disebabkan karena perbedaan pendekatan yang dipakai oleh mereka berbeda walaupun untuk satu obyek yang sama. Selain itu faktor zaman dan pandangan hidup yang melatarbelakangi mereka, serta tempat di mana mereka bermukim juga ikut mewarnai pemikiran mereka. Perlu kita ketahui bahwa perbedaan klasifikasi ini bukanlah sesuatu yang definitif dan formal, namun ia hanya berbeda dalam penekanan suatu sistem yang menjadi ciri khas dari suatu ajaran filsafat pendidikan tersebut.

Tiap-tiap aliran filsafat bukanlah merupakan usaha mengakhiri perbedaanperbedaan prinsipil dari suatu ajaran. Tetapi justru di dalam kebebasan memilih dan mengembangkan ide-ide filsafat itu, asas filosofis yang menghormati martabat kemanusiaan setiap orang tidak hanya teroritis adanya, melainkan praktis, dilaksanakan. Inilah satu bukti dan jaminan konkrit kebenaran-kebenaran filsafat yang asasi.

Jadi mengingkari kebebasan subyek, meniadakan eclecticisme bertentangan dengan asas-asas utama di dalam filsafat yang ideal. Dan ini perlahan-lahan tetapi pasti, membunuh perkembangan filsafat itu sendiri. Bahkan tidak adanya 
eclecticisme itu bertentangan dengan kodrat asasi pribadi manusia yang mengandung sifat-sifat individualitas dan sifat kepribadian yang unik. Klasifikasi aliran-aliran filsafat pendidikan berdasarkan perbedaan-perbedaan teori dan praktek pendidikan yang menjadi ide pokok masing-masing filsafat tersebut. Demikian pula klasifikasi itu sendiri akan berbeda-beda menurut cara dan dasar yang menjadi kriteria dalam menetapkan klasifikasi itu. Misalnya ada yang membuat klasifikasi aliran filsafat pendidikan berdasarkan asas dikotomi yakni antara aliran progressiv dan aliran conservative. Tetapi klasifikasi yang demikian sukar untuk menampung adanya kenyataan bahwa masing-masing aliran yang relatif banyak itu mempunyai pula segi-segi yang overlapping. Karena itu tak akan ada sifat yang murni bagi suatu aliran untuk digolongkan sebagai konservatif semata-mata, jika kita cukup jujur untuk melihat adanya unsur-unsur progressiv di dalamnya. Itulah sebabnya, perlu kita sadari bahwa klasifikasi aliran-aliran filsafat itu harus didasarkan atas penelitian yang mendalam dan sangat hati-hati.

\section{B. Pengertian Filsafat}

Filsafat adalah kata majemuk yang berasal dari bahasa Yunani, yakni philosophia dan philosophos (Sirajudin, 2007: 2). Philo, berarti cinta (loving), sedangkan sophia atau sophos, berarti pengetahuan atau kebijaksanaan (wisdom). Jadi, filsafat secara sederhana berarti cinta pada pengetahuan atau kebijaksanaan. Definisi filsafat menurut para filosof (Mustafa, 1997: 10):

1. Plato (427 SM - 348 SM) "Filsafat adalah ilmu pengetahuan yang berminat mencapai kebenaran yang asli."

2. Aristoteles (382 SM - $322 \mathrm{SM}$ ) "Filsafat adalah ilmu pengetahuan yang meliputi kebenaran yang terkandung di dalamnya ilmu-ilmu metafisika, logika,rektorika, etika, ekonomi, politik dan estetika."

3. Al Farabi (870 - 950) "Filsafat ialah ilmu pengetahuan tentang alam maujud dan bagaimana hakikat yang sebenarnya."

4. Descartes (1590 - 1650) "Filsafat adalah kumpulan segala pengetahuan dimana Tuhan, alam dan manusia menjadi pokok penyelidikan."

5. Immanuel Kant (1724 - 1804): "Filsafat adalah suatu pengetahuan yang menajadi pokok dan pangkal dari segala pengetahuan, yang tercakup didalam empat persoalan:

1) Apakah yang dapat kita ketahui? (Jawabnya: Metafisika)

2) Apa yang seharusnya kita ketahui? (Jawabnya: Etika)

3) Sampai dimanakah harapan kita? (Jawabnya: Agama)

4) Apakah yang dinamakan manusia? (Jawabnya: Antropologi)"

Dari berbagai definisi di atas dapat disimpulkan: "Filsafat adalah ilmu yang menyelidiki secara mendalam tentang Tuhan, alam semesta dan manusia untuk mencari kebenaran yang sejati”

\section{Pendidikan dalam Analisis Filsafat}

Brubacher dalam bukunya "Modern Philosophies of Education" merumuskan tentang deskripsi pendidikan sebagai berikut (Brubacher, 1962: 371) :

- Education should be thought of as the process of man's reciprocal adjustmen to nature, to his fellows, and to the ultemates nature of the cosmos.

- Education is the organized development and equipment of all the powers of human being, moral, intellectual, and physical, by and for their individual and social uses, directed to words the union of these activities with their creator as their final end. 
- Education in the process in which these powers (abilities, capacities) of men which are susceptible to habituation are perfected by good habits, by means artiscally contved and end employed by a men to help another or himself achieve the end in view (i. e., good habits).

Muhammad Noor Syam menyatakan bahwa pendidikan adalah aktivitas dan usaha manusia untuk meningkatkan kepribadiannya dengan jalan membina potensi-potensi pribadinya, yaitu ruhani (pikir, karsa, rasa, cipta, dan budi nurani) dan jasmani (panca indera serta keterampilan-keterampilan). Pendidikan berarti juga lembaga yang bertanggung jawab menetapkan cita-cita (tujuan), isi, sitem dan organisasi pendidikan. Lembaga-lembaga ini meliputi: keluarga, sekolah dan masyarakat (negara). Pendidikan juga merupakan hasil atau prestasi yang dicapai oleh perkembangan manusia dan usaha lembaga-lembaga pendidikan dalam mencapai tujuannya. Pendidikan dalam arti terakhir ini merupakan tingkat kemajuan masyarakat dan kebudayaan sebagai suatu kesatuan (Tim Dosen FIP-IKIP Malang, 1987: 7).

Dengan berdasar pada pengertian pendidikan sebagaimana disebutkan di atas, maka bisa dikatakan bahwa masalah pendidikan merupakan masalah hidup dan kehidupan manusia yang mencakup banyak aspek. Banyak masalah pendidikan yang mendasar yang tidak dapat dipecahkan dengan analisis ilmiah saja, tetapi juga diperlukan analisis yang mendalam, sistematis dan metodologis, yaitu dengan analisis filsafat. Dengan filsafat masalah-masalah pendidikan dapat dipecahkan dengan menggunakan pendekatan yang sebaik-baiknya.

\section{Apresiasi dan Kritik Terhadap Berbagai Aliran Filsafat Pendidikan 1. Perenialisme}

Perenialisme diambil dari kata perennial, yang dalam Oxford Advance learner's Dictionary of Current English diartikan sebagai "Continuing throghout the wole year" atau "Lasting for a very long time" - abadi atau kekal. Dari makna yang terkandung dalam kata itu, aliran perennialisme mengandung kepercayaan filsafat yang berpegang pada nilai-nilai dan norma-norma yang bersifat kekal abadi (Zuhairini, 1992: 27).

Perenialisme mengambil jalan regresif, karena mempunyai pandangan bahwa tidak ada jalan lain kecuali kembali kepada prinsip umum yang telah menjadi dasar tingkah laku dan perbuatan zaman kuno dan abad pertengahan. Perennialisme melihat bahwa akibat dari kehidupan zaman modern telah menimbulkan banyak krisis di berbagai bidang kehidupan manusia. Oleh sebab itu perennialisme memandang penting peranan pendidikan dalam proses mengembalikan keadaan manusia zaman modern ini kepada kebudayaan masa lampau yang dianggap cukup ideal dan yang telah terpuji ketangguhanya.

Apresiasi terhadap aliran filsafat ini adalah, bahwa filsafat ini akan menonjolkan wawasan kependidikan Islam era salaf, sehingga pendidikan Islam berfungsi sebagai upaya melestarikan dan mempertahankan nilai-nilai Ilahiyah dan insaniyah, juga kebiasaan dan tradisi masyarakat salaf (era kenabian dan sahabat), karena mereka dipandang sebagai masyarakat yang ideal. Aliran ini berusha menjadikan nash AlQur'an dan Sunnah dengan tanpa menggunakan pendekatan keilmuan lain, dan menjadikan masyarakat salaf sebagai parameter untuk menjawab tantangan dan perubahan zaman serta era modernitas.

Akan tetapi aliran ini terlalu kolot dan konservatif terhadap segala perubahan dan perkembangan zaman. Segala sesuatunya dipahami secara tektualis dengan mengacu terhadap dua pegangan umat Islam yaitu Al-Qur'an dan Sunnah dan juga watak 
konservatifnya untuk mempertahankan dan melestarikan nilai-nilai Ilahiyah dan insaniyah yang dipraktikkan pada masa salaf. Apabila menyimpang dari kedua nash tersebut dan tidak sesuai dengan generasi salaf, maka dapat dipastikan hukumnya bid'ah bahkan bisa haram.

\section{Esensialisme}

Adalah suatu filsafat pendidikan konservatif yang pada mulanya dirumuskan sebagai suatu kritik pada trend-trend progresif di sekolah-sekolah. Mereka berpendapat bahwa pergerakan progresif telah merusak standar-standar intelektual dan moral di antara kaum muda. Esensialisme didasari atas pandangan humanisme yang merupakan reaksi terhadap hidup yang mengarah pada keduniawian, serba ilmiah dan materialistik. Tujuan umum aliran esensialisme adalah membentuk pribadi bahagia di dunia dan akhirat. Kurikulum sekolah bagi esensialisme merupakan semacam miniatur dunia yang bisa dijadikan sebagai ukuran kenyataan, kebenaran dan kegunaan. Maka dalam sejarah perkembanganya, kurikulum esensialisme menerapkan berbagai pola kurikulum, seperti pola idealisme, realisme dan sebagainya (Syam, 1986: 153).

Aliran esensialisme banyak diterapkan di beberapa lembaga pendidikan Islam di Indonesia khususnya pondok pesantren salaf. Aliran ini mengacu pada ajaran empat mazhab dan ulama-ulama era klasik, sehingga cocok sekali diterapkan di Indonesia yang mayoritas umat Islamnya bermazhab Sunni. Aliran ini terbukti mampu melahirkan tokoh-tokoh kaliber nasional dan internasional seperti KH. Ahmad Dahlan, KH. Hasyim Asy'ari, Buya Hamka, Gus Dur dan masih banyak lagi tokoh-tokoh yang lahir dari pendidikan pondok pesantren.

Akan tetapi para penganut aliran ini biasanya bersifat fanatik terhadap tokohtokoh era klasik serta ijtihad-ijtihad yang mereka hasilkan, seperti produk hukumhukum Islam terutama yang berkaitan dengan fiqih. Mereka sering memperdebatkan masalah-masalah furu'iyah yang berkaitan dengan ibadah, misalnya berdebat masalah doa qunut, tahlil, ziarah dan sebagainya.

\section{Progresivisme}

Progresivisme dalam pandanganya selalu berhubungan dengan pengertian "the liberal road to culture" yakni liberal dimaksudkan sebagai fleksibel (lentur tidak kaku), toleran dan bersikap terbuka, serta ingin mengetahui dan menyelidiki demi pengembangan pengalaman (Djumberansyah, 1994: 130).

Progresivisme menolak otoritarisme dan absolutisme dalam segala bentuk, seperti misalnya terdapat dalam agama, politik dan etika. Akan tetapi progressivisme menaruh kepercayaan terhadap kekuatan alamiah dari manusia (Zuhairini, 1992: 21). Progresivisme disebut juga sebagai naturalisme yang mempunyai pandangan bahwa kenyataan yang sebenarnya adalah alam semesta ini (bukan kenyataan spiritual dan supernatural). Progresivisme juga identik dengan experimentalisme berarti aliran ini menyadari dan mempraktekkan bahwa eksprimen (percobaan ilmiah) adalah alat utama untuk menguji kebenaran suatu teori dan suatu ilmu pengetahuan.

Aliran ini terbukti dapat membangun era kuno menjadi era modern seperti era saat ini. Perkembangan ilmu pengetahuan semakin cepat dan arus komunikasi semakin mudah. Semua ini merupakan efek dari progresivisme. Dalam konteks Islam di Indonesia, aliran ini melahirkan pemikir-pemikir yang berpikiran liberal, sebut saja Nurcholis Majid, Azzumardy Azra, Jalaluddin Rahmad, Qomaruddin Hidayat, Ulil Absor Abdalla dan masih banyak lagi tokoh-tokoh yang lahir dari aliran progresivisme. Mereka berusaha menginterpretasikan ajaran-ajaran Islam dengan menggunakan akal atau rasio. 
Tujuan pendidikan Islam dalam aliran ini diorientasikan pada upaya-upaya memberikan ketrampilan-ketrampilan dan alat-alat kepada peserta didik yang dapat dipergunakan untuk berinteraksi dengan lingkunganya yang selalu berada dalam proses perubahan sehingga ia bersifat dinamis dalam menghadapi dan meresppon tuntutan dan kebutuhan-kebutuhan lingkunganya, serta mampu menyesuaikan dan melakukan penyesuaian kembali dengan tuntutan perubahan sosial dan iptek.

\section{Rekonstruksionisme}

Pada dasarnya aliran rekonstruksionalisme adalah sepaham dengan aliran perenialisme dalam hendak mengatasi krisis kehidupan modern. Hanya saja jalan yang ditempuhnya berbeda dengan apa yang dipakai oleh perenialisme, tetapi sesuai dengan istilah yang dikandungnya, yaitu berusaha membina suatu konsensus yang paling luas dan paling mungkin tentang tujuan utama dan tertinggi dalam kehidupan manusia (Zuhairini, 1992: 29).

Rekonstruksionalisme berusaha mencari kesepakatan semua orang mengenai tujuan utama yang dapat mengatur tata kehidupan manusia dalam suatu tatanan baru seluruh lingkunganya. Maka melalui lembaga dan proses pendidikan, aliran ini ingin merombak tata susunan lama dan membangun tata susuna hidup kebudayaan yang sama sekali baru. Dan tujuan ini hanya dapat diwujudkan dengan melalui usaha bersama, bekerja sama semua bangsa-bangsa.

Para penganut aliran ini berkeyakinan bahwa bangsa-bangsa di dunia mempunyai hasrat yang sama untuk menciptakan satu dunia baru, dengan satu kebudayaan baru di bawah satu kedaulatan dunia, dalam pengawasan mayoritas umat manusia.

\section{Eksistensialisme}

Memfokuskan pada pengalaman-pengalaman individu. Secara umum, eksistensialisme menekankan pilihan kreatif, subjektifitas pengalaman manusia dan tindakan konkrit dari keberadaan manusia atas setiap skema rasional untuk hakekat manusia atau realitas. Aliran ini hendak memadukan hidup yang dimiliki dengan pengalaman dan situasi sejarah yang dia alami dan tidak mau terikat oleh hal-hal yang sifatnya absatrak dan spekulatif. Atas dasar pandangan itu, sikap di kalangan kaum eksistensialisme seringkali nampak aneh atau lepas dari norma-norma umum. Kebebasan/freedom adalah lebih banyak menjadi ukuran dalam sikap dan perbuatanperbuatanya.

\section{E. Paradigma Pengembangan dan Implementasinya}

\section{Perennialisme}

Aliran ini berupaya memahami ajaran-ajaran dan nilai-nilai mendasar yang terkandung dalam Al-Qur'an dan Al-Sunnah dengan melepaskan diri dan kurang begitu mempertimbangkan situasi konkret dinamika pergumulan masyarakat Muslim (era klasik maupun kontemporer) yang mengitarinya. Masyarakat ideal yang diidamidamkan adalah masyarakat salaf, yakni struktur masyarakat era kenabian Muhammad Saw. Dan para sahabat yang menyertainya (Zuhairini, 1992: 88). Rujukan utama pemikirannya adalah kitab suci Al-Qur'an dan kitab-kitab Hadits. Tanpa menggunakan pendekatan keilmuan yang lain. Dengan kata lain model yang pertama ini sangat mementingkan dalil-dalil nash ayat-ayat Al-Qur'an dan Hadist. Sehingga model pemikiran ini terlihat kurang peka terhadap perubahan dan hanya menjadikan masyarakat salaf sebagai parameter dalam menjawab tantangan dan perubahan zaman serta era modernitas. 
Pendidikan adalah usaha untuk membantu atau menolong mengembangkan manusia sebagai makhluk individu dan sekaligus makhluk sosial, makhluk susila dan makhluk keagamaan. Wahyu yang pertama kali diturunkan mengandung perintah untuk membaca. Dari wahyu pertama itu pula, dapat diambil suatu kesimpulan bahwa Islam memerintahkan supaya belajar yang merupakan sarana peningkatan terbaik untuk mencerdaskan umat manusia, khususnya bila ilmu yang dipunyai tersebut diikuti dengan amal shalih (Ridlwan, 2005: 59).

\section{Esensialisme}

Aliran ini berupaya memahami ajaran-ajaran dan nilai-nilai mendasar yang terkandung dalam Al-Qur'an dan Hadis melalui bantuan khazanah pemikiran Islam klasik, tapi sering kali kurang begitu mempertimbangkan situasi sosio historis masyarakat setempat dimana ia turut di dalamnya. Hasil pemikiran ulama terdahulu dianggap sudah pasti atau absolut tanpa mempertimbangkan dimensi historisnya.

Karena wataknya yang tradisional dan mazhabi tersebut, maka dalam pengembangan pemikiran (filsafat) pendidikan ia lebih menekankan pada pemberian syarah (penjelasan dari substansi materi-materi pemikiran para pendahulunya) serta hasyiyah (catatan kaki) terhadap materi-materi pemikiran para pendahulunya yang menjadi sumber acuanya, dan tidak ada keberanian untuk mengubah substansi materi pemikiran pendahulunya. Karena wataknya yang semacam itu, sehingga ia lebih dekat dengan perenialisme dan essensialisme terutam dilihat dari wataknya yang regresif dan konservatif.

Dalam konteks pemikiran filsafat pendidikan Islam, tipologi tersebut berusaha membangun konsep pendidikan Islam melalui kajian terhadap khazanah pemikiran pendidikan Islam karya para ulama pada periode-periode terdahulu, baik dalam bangunan tujuan pendidikanya, kurikulum atu program pendidikan, hubungan pendidik dan peserta didik, metode pendidikan, maupun lingkungan pendidikan.

\section{Progresivisme}

Aliran ini berupaya memahami ajaran-ajaran dan nilai-nilai mendasar yang terkandung dalam Al-Qur'an dan Sunnah dengan hanya semata-mata mempertimbangkan kondisi dan tantangan sosio historis dan kultural yang dihadapi oleh masyarakat muslim kontemporer, tanpa mempertimbangkan muatan-muatan khazanah intelektual muslim era klasik yang terkait dengan persoalan keagamaan dan kemasyarakatan.

Karena wataknya yang seperti itu, sehingga ia tidak berkepentingan untuk merujuk pada pemikiran-pemikiran dan praktek sistem pendidikan dari para pendahulunya, sebab ia hanya dianggap relevan dalam konteks sosio- historis dan kulturalnya sendiri. Justru ia dianggap sudah ketinggalan zaman dan kurang relevan untuk memenuhi tuntutan kebutuhan dan perubahan-perubahan sosial yang terjadi pada era sekarang..

\section{Rekonstruksionisme}

Kata rekonstruksionisme dalam bahasa Inggris rekonstruct yang berarti menyusun kembali. Dalam konteks filsafat pendidikan, aliran rekonstruksionisme adalah suatu aliran yang berusaha merombak tata susunan lama dan membangun tata susunan hidup kebudayaan yang bercorak modern. Aliran rekonstruksionisme, pada prinsipnya, sepaham dengan aliran perenialisme, yaitu hendak menyatakan krisis kebudayaan modern. Kedua aliran tersebut, aliran rekonstruksionisme dan perenialisme, memandang bahwa keadaan sekarang merupakan zaman yang mempunyai kebudayaan yang terganggu oleh kehancuran, kebingungan dan kesimpangsiuran. 
Aliran rekonstruksionisme berkeyakinan bahwa tugas penyelamatan dunia merupakan tugas semua umat manusia atau bangsa. Karenanya pembinaan kembali daya inetelektual dan spiritual yang sehat akan membina kembali manusia melalui pendidikan yang tepat atas nilai dan norma yang benar pula demi generasi sekarang dan generasi yang akan datang, sehingga terbentuk dunia baru dalam pengawasan umat manusia. Kemudian aliran ini memiliki persepsi bahwa masa depan suatu bangsa merupakan suatu dunia yang diatur, diperintah oleh rakyat secara demokratis dan bukan dunia yang dikuasai oleh golongan tertentu. Sila-sila demokrasi yang sungguh bukan hanya leori tetapi mesti menjadi kenyataan, sehingga dapat diwujudkan suatu dunia dengan potensi-potensi teknologi, mampu meningkatkan kualitas kesehatan, kesejahteraan dan kemakmuran serta keamanan masyarakat tanpa membedakan warna kulit, keturunan, nasionalisme, agama (kepercayaan) dan masyarakat bersangkutan.

sekolah harus bersatu dengan kekuatan buruh progresiv, wanita, para petani, dan kelompok minoritas untuk mengadakan perubahan-perubahan yang diperlukan. Counts mengkritik pendidikan progresiv telah gagal menghasilkan teori kesejahteraan sosial dan mengatakan sekolah dengan pendekatan child centered tidak cocok untuk menentukan pengetahuan dan skill sesuai dalam abad dua puluh (Uyoh, 2003: 168-169).

\section{Eksistensialisme}

Eksistensialisme biasa dialamatkan sebagai salah satu reaksi dari sebagian terbesar reaksi terhadap peradaban manusia yang hampir punah akibat perang dunia kedua (Fernando, 1969: 1).

Aliran ini memfokuskan pada pengalaman-pengalaman individu. Secara umum, eksistensialisme menekankan pilihan kreatif, subjektifitas pengalaman manusia dan tindakan konkrit dari keberadaan manusia atas setiap skema rasional untuk hakekat manusia atau realitas. Aliran ini hendak memadukan hidup yang dimiliki dengan pengalaman dan situasi sejarah yang dia alami dan tidak mau terikat oleh hal-hal yang sifatnya absatrak dan spekulatif. Atas dasar pandangan itu, sikap di kalangan kaum eksistensialisme seringkali nampak aneh atau lepas dari norma-norma umum. Kebebasan/freedom adalah lebih banyak menjadi ukuran dalam sikap dan perbuatanperbuatanya.

\section{F. Kesimpulan}

Filsafat adalah hasil pemikiran ahli-ahli filsafat atau filosof-filosof sepanjang zaman diseluruh dunia. Sejarah pemikiran filsafat yang amat panjang dibandingkan dengan sejarah ilmu pengetahuan, telah memperkaya khazanah (perbendaharaan) ilmu filsafat. Sebagai ilmu tersendiri filsafat tidak saja telah menarik minat dan perhatian para pemikir, tetapi bahkan filsafat telah amat banyak mempengaruhi perkembangan keseluruh budaya umat manusia. Filsafat telah mempengaruhi sistem politik, sistem sosial, sistem ideologi semua bangsa-bangsa-bangsa. Juga filsafat mempengaruhi sistem ilmu pengetahuan itu sendiri, yang tersimpul di dalam filsafat ilmu pengetahuan tertentu seperti filsafat huku, filsafat ekonomi, filsafat ilmu kedokteran, filsafat pendidikan dan sebagainya. Akhirnya yang pokok dari semua itu, filsafat telah mempengaruhi sikap hidup, cara berpikir, kepercayaan atau ideologinya. Filsafat telah mewarisi subyek atau pribadi sedemikian kuat, sehingga tiap orang menjadi penganut suatu faham filsafat baik sadar maupun tidak, langsung ataupun tidak langsung. Aliran-aliran filsafat pendidikan memberi arti penting bagi perkembangan dunia pendidikan. Hal ini bisa di lihat, dari tahunketahun perkembangan ilmu pengetahuan di lembaga pendidikan semakin pesat. 
Pengembangan-pengembangan tersebut merupakan dampak dari adanya aliranaliran filsafat.

\section{DAFTAR PUSTAKA}

Assegaf, Abdurrahman \& Suyadi. 2008. Pendidikan Islam Mazhab Kritis: Perbandingan Teori Pendidikan Timur dan Barat. Yogyakarta: Gema Media.

Barnadib, Imam. 1990. Filsafat Pendidikan: Pengantar Mengenai Sistem dan Metode. Jogjakarta: Andi Offset.

Brubacher, John S. 1962. Modern Philosopy of Education. Tokyo: Kugakusha Company Ltd.

Gandhi, Teguh Wangsa. 2011. Filsafat Pendidikan. Yogjakarta: Ar-Ruzz Media.

Indar, Djumberansyah. 1994. Filsafat Pendidikan. Surabaya: Karya Aditama.

Jaiz, Hartono Ahmad. Bahaya Islam Liberal. diambil dari E-Book.

Jalaluddin \& Abdullah Idi. 2007. Filsafat Pendidikan Manusia. Filsafat dan Pendidikan. Yogyakarta: Ar-Ruzz Media.

Mudyahardjo, Redja. 2002. Pengantar Pendidikan. Jakarta : PT Raja Grafindo Persada.

Muhaimin. 2004. Wacana Pengembangan Pendidikan Islam. Yogyakarta: Pustaka Pelajar.

----------. 2003. Arah Baru Pengembangan Pendidikan Islam. Bandung: Yayasan Nuansa Cendekia.

Molina, Fernando R. 1969. The Sources of Eksistentialism as Philosophys. Jersey: Prentice-Hall.

Mustofa, A. 1997. Filsafat Islam. Jakarta: CV. Pustaka Setia.

Nasir, Ridlwan. 2005. Mencari Tipologi Format Pendidikan Ideal Pondok Pesantren di Tengah Arus Perubahan. Yogyakarta: Pustaka Pelajar.

Nasution, Harun. 1985. Akal dan Wahyu Dalam Islam. Jakarta: Universitas Indonesia.

Ramayulis dan Samsul Nizar. 2009. Filsafat Pendidikan Islam; Telaah Sistem Pendidikan dan Pemikiran Para Tokohnya. Jakarta: Kalam Mulia

Sadullah, Uyoh. 2003. Pengatar Filsafat Pendidikan. Bandung: Alfabeta.

Suriasumantri, Jujun S. 1985. Filsafat Ilmu Sebuah Pengantar Populer. Jakarta: Sinar Harapan.

Syam, Mohammad Noor. 1986. Filsafat Pendidikan dan Dasar Filsafat Pendidikan Pancasila. Surabaya: Usaha Nasional.

Tafsir, Ahmad. 1998. Filsafat Umum Akal dan Hati Sejak Thales Sampai James. Bandung: Remaja Rosda Karya.

Zar, Sirajudin. 2007. Filsafat Islam: Filosof dan Filsafatnya. Jakarta: PT. Raja Grafindo Persada.

Zuhairini, dkk. 1992. Filsafat Pendidikan Islam. Jakarta: Bumi Aksara. 